\title{
Water Quality Threats, Perceptions of Climate Change and Behavioral Responses among Farmers in the Ethiopian Rift Valley
}

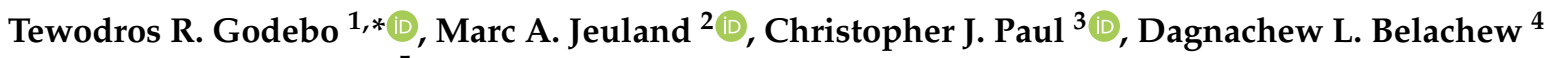 \\ and Peter G. McCornick ${ }^{5}$ \\ 1 Department of Environmental Health Sciences, School of Public Health and Tropical Medicine, \\ Tulane University, New Orleans, LA 70112, USA \\ 2 Sanford School of Public Policy and Duke Global Health Institute, Duke University, P.O. Box 90239, \\ Durham, NC 27708, USA; marc.jeuland@duke.edu \\ 3 Department of Public Administration, North Carolina Central University, 1801 Fayetteville St, \\ Durham, NC 27707, USA; cpaul5@nccu.edu \\ 4 School of Earth Sciences, Addis Ababa University (AAU), Addis Ababa P.O. Box 1176, Ethiopia; \\ dagnachew.legesse@aau.edu.et \\ 5 Daugherty Water for Food Global Institute (DWFI), University of Nebraska, Lincoln, NE 68588, USA; \\ pmccornick@nebraska.edu \\ * Correspondence: tgodebo@tulane.edu
}

check for

updates

Citation: Godebo, T.R.; Jeuland, M.A.; Paul, C.J.; Belachew, D.L.; McCornick, P.G. Water Quality Threats, Perceptions of Climate Change and Behavioral Responses among Farmers in the Ethiopian Rift Valley. Climate 2021, 9, 92. https:// doi.org/10.3390/cli9060092

Academic Editor: Steven McNulty

Received: 18 May 2021

Accepted: 2 June 2021

Published: 6 June 2021

Publisher's Note: MDPI stays neutral with regard to jurisdictional claims in published maps and institutional affiliations.

Copyright: (C) 2021 by the authors Licensee MDPI, Basel, Switzerland. This article is an open access article distributed under the terms and conditions of the Creative Commons Attribution (CC BY) license (https:/ / creativecommons.org/licenses/by/ $4.0 /)$.

\begin{abstract}
This work aims to assess water quality for irrigated agriculture, alongside perceptions and adaptations of farmers to climate change in the Main Ethiopian Rift (MER). Climate change is expected to cause a rise in temperature and variability in rainfall in the region, reducing surface water availability and raising dependence on groundwater. The study data come from surveys with 147 farmers living in the Ziway-Shala basin and water quality assessments of 162 samples from groundwater wells and surface water. Most groundwater samples were found to be unsuitable for long term agricultural use due to their high salinity and sodium adsorption ratio, which has implications for soil permeability, as well as elevated bicarbonate, boron and residual sodium carbonate concentrations. The survey data indicate that water sufficiency is a major concern for farmers that leads to frequent crop failures, especially due to erratic and insufficient rainfall. An important adaptation mechanism for farmers is the use of improved crop varieties, but major barriers to adaptation include a lack of access to irrigation water, credit or savings, appropriate seeds, and knowledge or information on weather and climate conditions. Local (development) agents are identified as vital to enhancing farmers' knowledge of risks and solutions, and extension programs must therefore continue to promote resilience and adaptation in the area. Unfortunately, much of the MER groundwater that could be used to cope with declining viability of rainfed agriculture and surface water availability, is poor in quality. The use of saline groundwater could jeopardize the agricultural sector, and most notably commercial horticulture and floriculture activities. This study highlights the complex nexus of water quality and sufficiency challenges facing the agriculture sector in the region, and should help decision-makers to design feasible strategies for enhancing adaptation and food security.
\end{abstract}

Keywords: climate change; perception; adaptation; irrigation water quality; agriculture; smallholder farmers; Ethiopia Rift Valley

\section{Highlights}

- Most groundwater and lake waters in the Ethiopian Rift are unsuitable for agricultural use.

- Lack of and erratic rainfall are the main causes of crop failure in the region. 
- Use of improved seeds constitutes the primary adaptation for dealing with water scarcity.

- Barriers to adaptation include limited access to water, credit/savings, improved seeds, and weather/climate information.

- Extension (development) agents are critical for enhancing farmers' knowledge and adaptability to climatic variability.

\section{Introduction}

Climate change impact assessment studies have shown that changes in quantities and variability of rainfall, as well as rising temperatures, are increasing stress in many agriculture and water systems, and affecting human and ecological health and well-being, with likely worsening effects in the future [1-5]. Although the specific magnitude of these changes and their consequences is subject to scientific uncertainty and regional heterogeneity, there is high confidence that the agricultural sector is particularly vulnerable, and that negative impacts will be concentrated in developing countries [1,6-11]. This may be particularly true for semi-arid regions of African countries, where local economies typically remain heavily reliant on climate-sensitive and low productivity rainfed agriculture [10-12]. Other major drivers, such as urbanization, population growth, competition for and degradation of water and natural resources, and other developments, are creating new challenges for local environments and communities [13-17]. Ethiopia is a prototypical example with a large and rapidly growing population of about 110 million [18], 80\% of whose livelihoods are provided by agriculture [19]. The agriculture sector in Ethiopia is extremely important, as it contributes about one-third of the nation's GDP [19-21]. Additionally, while there has been notable progress in improving agricultural productivity in recent years, there is still considerable scope to intensify production and thereby increase food security at local and national levels [22,23]. Meanwhile, climate change threatens to undo this progress [24]. This study focuses on the Main Ethiopian Rift (MER), a semi-arid region where livelihoods are dominated by subsistence rainfed agriculture, and where water availability is highly seasonal and has high interannual variability [25-27].

Agriculture in the MER, as in many regions of Sub-Saharan African countries, is characterized by high labor inputs, low capitalization and mechanization, routine occurrence of water deficits relative to crop requirements, and resultant low productivity. Difficult cultivation conditions constrain farmers' net incomes and capacity for investing in strategies that advance productivity and improve resilience to existing variability, and inhibit modernization of the agricultural sector. Given the already delicate hydrological balance in such regions $[15,24]$, and the need to increase agricultural production, additional reduction of precipitation or increased variability under climate change will add to existing pressure on local populations, and could compromise the livelihoods of millions of rural inhabitants. To build resilience and reduce vulnerability, proactive planning is vital for adaptation to climate change and coping with a wide set of agricultural and water sector stressors [28]. Farmers are aware of environmental change and use a variety of strategies to adapt $[10,29,30]$.

In the agricultural sector, common adaptation methods include the promotion of crop varieties and livestock species that are better suited to dry and hot conditions, irrigation, crop diversification, adoption of mixed crop and livestock farming systems, and shifting of planting dates [31-35]. The provision or expansion of irrigated agriculture, whether small-scale/farmer-led, large scale public or commercial investment, or some combination thereof [36], could serve to relieve problems stemming from water variability and seasonal water scarcity. At the same time, however, irrigated agriculture, especially that supported by large-scale public systems, creates its own sustainability challenges, since such systems can be costly to develop, manage, and maintain [37]. In the MER, for example, where irrigated farms are currently expanding, water quality studies indicate that many water resources are highly saline (e.g., $\mathrm{Na}, \mathrm{Cl}$, and $\mathrm{B}$ ) and unsuitable for irrigation over the long term $[38,39]$. The effects of low-quality irrigation water may not always be appar- 
ent immediately, as these relate to soil characteristics such as permeability, and to crop choices, especially when soils are already saline and alkaline. Salinity and sodium hazard indicators - such as the sodium adsorption ratio (SAR) [40-42] — can be used to assess the suitability of irrigation water sources [43-45], as excessive $\mathrm{Na}^{+}$concentrations and salinity can affect both soil and crops. High $\mathrm{Na}^{+}$content in irrigation water can enhance cation-exchange replacement of $\mathrm{Na}^{+}$in water to $\mathrm{Ca}^{2+}$ and $\mathrm{Mg}^{2+}$ ions in the soil, thereby reducing soil permeability and water infiltration [46].

This study discusses results obtained from an agricultural survey conducted to understand farmers' sensitivity and perceptions of changing climate, and to explore the influence of these on crop production and other adaptation choices. The type and role of adaptation mechanisms to complex regional stressors were assessed across a range of agro-climatic microzones within the Ziway-Shala Basin of the MER. In addition to these surveys, the quality of surface and groundwater sources was assessed to determine the suitability of these for irrigation use in the region. Understanding these aspects is critical for enhancing policy responses in the region, and is of great importance for the sustainable development of its agricultural sector under future climate and environmental change.

\section{Study Area and Regional Setting}

The study area comprises two large basins; the Ziway-Shala and Abaya-Chamo, plus a small catchment (Awasa) located in the central portion of the Main Ethiopian Rift (MER) valley. The MER is characterized by a chain of lakes (Ziway-Langano-AbijataShala-Awasa-Abaya-Chamo) that lie at an average altitude of $1600 \mathrm{~m}$ above sea level (m.a.s.l). These lakes receive surface inflow from rivers and springs that drain the western and eastern highlands (elevation above 2500 m.a.s.l. on average) bordering the MER. The climatic conditions in the highlands, along the escarpment, and on the Rift valley floor differ dramatically. Mean annual rainfall in the highlands ranges from about $800 \mathrm{~mm}$ to over $2400 \mathrm{~mm}$, while the Rift valley is semi-arid to arid, with rainfall varying from $300 \mathrm{~mm}$ to $800 \mathrm{~mm}[47,48]$. The mean annual temperature in the highlands is less than $15^{\circ} \mathrm{C}$ and evaporation does not exceed $1000 \mathrm{~m}$ per year; on the Rift floor, the mean temperature is greater than $20^{\circ} \mathrm{C}$, and evaporation exceeds $2500 \mathrm{~mm}$ [49]. Rainfall in the Rift is concentrated during the summer months from June to September, with additional modest rains coming from March to May. During the long, dry period between October and February, water is extremely scarce. Overall, because evapotranspiration significantly exceeds rainfall, the water quality in the Rift valley, particularly in its lakes, is highly degraded. Nonetheless, surface and groundwater resources are currently used by many of the region's small-scale agroindustries, commercial irrigators, and floriculture farms.

Indeed, one of the notable developments in past decades has been the introduction and rapid expansion of irrigated agricultural activity. A continuum of scales and business models from smallholder farmer irrigation schemes (i.e., farmer-led irrigated agriculture) to large scale private and state farms have been established over this period. Foreign and national investment and expertise has flowed in to support such enterprises and stimulate production in enclosed vegetable and flower cultivation areas.

\section{Materials and Methods}

This study combined water sampling and testing and smallholder surveys to obtain a comprehensive view of farming options for coping with climate change. Descriptions of each of these follow below.

\subsection{Water Sampling and Analysis}

Groundwater and surface water samples that are used for drinking and irrigation (specifically those surface waters surveyed around Lake Ziway and Arata), were collected in the Ziway-Shala and Abaya-Chamo basins in April-May 2010, March 2011 and November 2012. A total of 162 water samples were collected from 135 groundwater wells, 8 cold springs, 8 rivers and 11 lakes (Figure 1). The groundwater samples were most typically 
collected from active pumping wells, after allowing the water to flow for a few minutes. Samples from springs and lakes were collected at the mouth of the source and 50-100 m away from the shore, respectively. First, in situ measurements of $\mathrm{pH}$, temperature and electrical conductivity (EC) were conducted for all samples. Next, samples for major and trace element analysis were filtered in the field using $0.45 \mu \mathrm{m}$ filters, directly into $60 \mathrm{~mL}$ polyethylene bottles. These bottles had been cleaned with trace metal grade $\sim 1 \mathrm{~N} \mathrm{HCl}$ and $\sim 1 \mathrm{~N} \mathrm{HNO}_{3}$ and then rinsed with deionized water having resistivity $>18 \mathrm{M} \Omega / \mathrm{cm}$. Major cation/trace metal samples were immediately acidified with high-purity $\mathrm{HNO}_{3}$ (Fisher Optima). Unfiltered and unacidified samples were also collected into $60 \mathrm{~mL}$ and $30 \mathrm{~mL}$ polyethylene bottle to allow measurement of alkalinity.

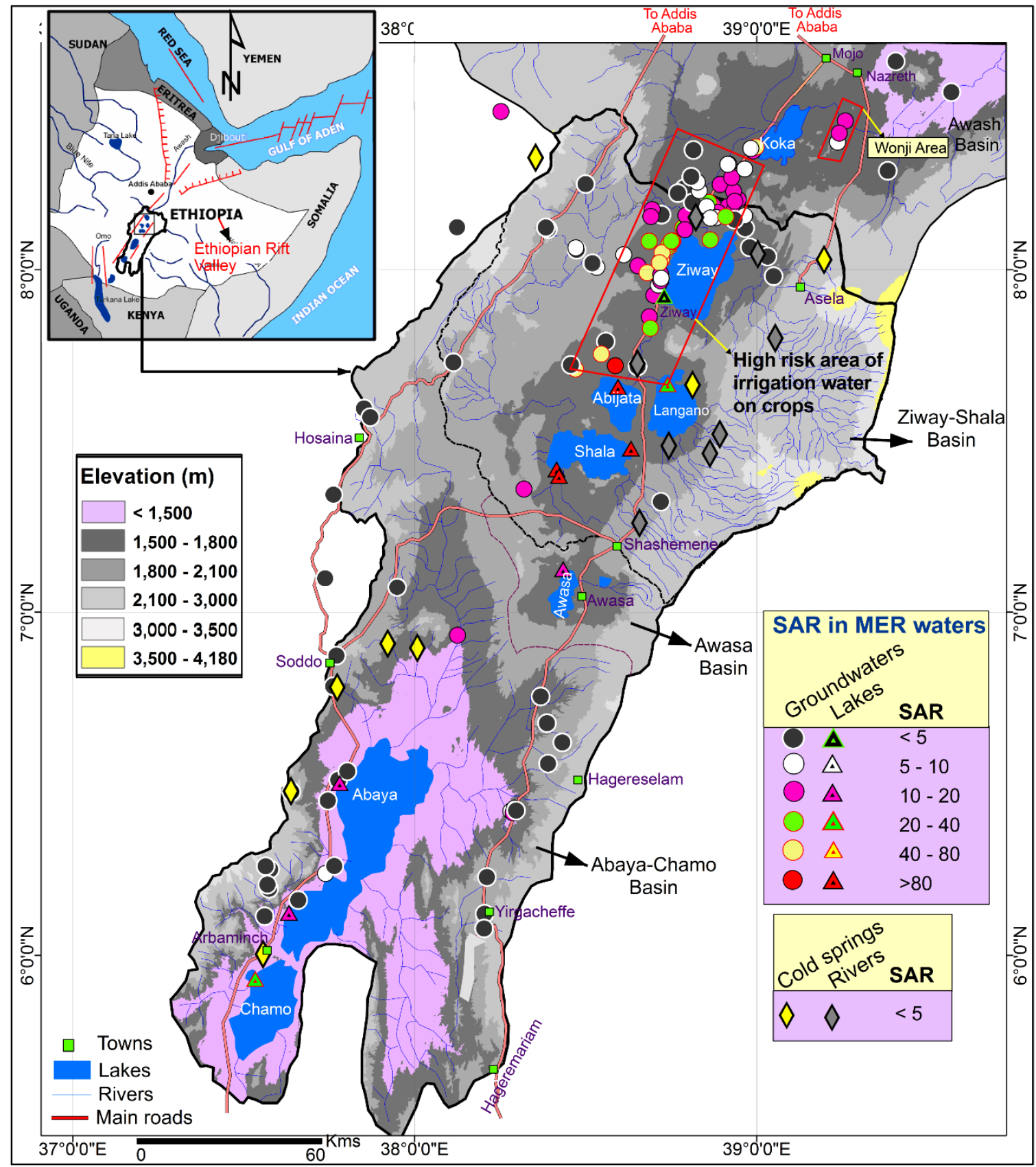

Figure 1. Distribution of water sampling sites in the MER according to type (groundwater, lakes, cold springs and rivers). SAR values are color-coded. Note that the red rectangle represents an area where use of poor quality water for irrigation purposes poses substantial risks. 
Concentrations of major cations-calcium $\left(\mathrm{Ca}^{2+}\right)$, magnesium $\left(\mathrm{Mg}^{2+}\right)$, sodium $\left(\mathrm{Na}^{+}\right)$, and silica $\left(\mathrm{SiO}_{2}\right)$-were measured using a direct-current plasma spectrometer (DCP) calibrated using solutions prepared from plasma-grade single-element standards. Major anions of chloride $\left(\mathrm{Cl}^{-}\right)$, sulfate $\left(\mathrm{SO}_{4}{ }^{2-}\right)$, and nitrate $\left(\mathrm{NO}_{3}{ }^{-}\right)$were analyzed using an ion chromatograph (IC). Total alkalinity $\left(\right.$ as $\mathrm{HCO}_{3}{ }^{-}$) was measured using titration techniques to $\mathrm{pH}$ 4.5. Trace elements-boron (B) and other trace metals-were analyzed via a PerkinElmer Elan 5000 inductively coupled plasma-mass spectrometer (ICP-MS), calibrated to the National Institute of Standards and Technology (NIST) 1643e standard.

\subsection{Water Quality Parameters for Agriculture}

The most important constituents of concern for agriculture include several major ions $\left(\mathrm{Na}^{+}, \mathrm{Cl}^{-}, \mathrm{HCO}_{3}{ }^{-}, \mathrm{Ca}^{2+}\right.$ and $\left.\mathrm{Mg}^{2+}\right)$, and trace elements such as boron. Critical parameters that constrain soil permeability and crop yields are salinity (as electrical conductivity; EC), the sodium adsorption ratio (SAR; defined as $\left.\mathrm{SAR}=\mathrm{Na}^{+} / \sqrt{ }\left(\mathrm{Ca}^{2+}+\mathrm{Mg}^{2+}\right) / 2\right)$ ) or percent sodium (defined as Percent $\left.\mathrm{Na}=\mathrm{Na}^{+} /\left(\mathrm{Na}^{+}+\mathrm{K}^{+}+\mathrm{Ca}^{2+}+\mathrm{Mg}^{+2}\right) * 100\right)$, and residual sodium carbonate $\left(\mathrm{RSC}\right.$; defined as $\left.\mathrm{RSC}=\left(\mathrm{CO}_{3}{ }^{2-}+\mathrm{HCO}_{3}{ }^{-}\right)-\left(\mathrm{Ca}^{2+}+\mathrm{Mg}^{+2}\right)\right)$.

\subsection{Farmer Surveys}

A cross-sectional transect survey was conducted across different agro-climatic zones spanning from the highlands to the escarpment and then to the Rift floor in the ZiwayShala basin (Figure 2). In order to select for variation in growing conditions, clusters of communities conveniently accessible at each location were enrolled along the main road transect but situated at different elevations, or that were identified through prior discussions with local government (e.g., water) offices. A total of 147 farmers (143 male and 4 female subjects) aged between 19 and 77 years (mean: 43.7 years) were then interviewed in December-January 2012. Upon identifying a sample community at a given elevation, field workers approached households in a community and presented a formal letter from Addis Ababa University about the study and were asked if they consented to be interviewed. All respondents granted informed consent, and the anonymity of all investigated subjects has been preserved. Each farm surveyed was assigned a unique identifying code enabling it to be matched to spatially referenced data on weather and climate.

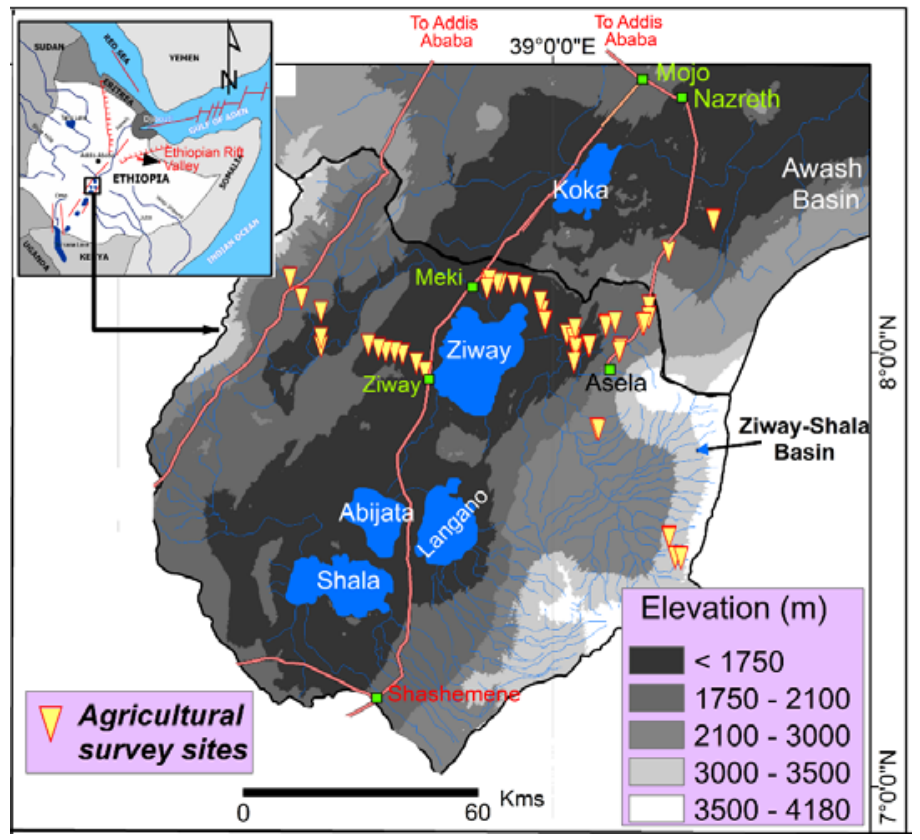

Figure 2. Location of agricultural survey sites. 
During face-to-face interviews, data were collected on the farmer's household characteristics; land ownership; animal husbandry; cropping; input costs (e.g., for seeds, fertilizer and pesticides); factors affecting crop yield; source(s) of water for agriculture (rainfed or irrigation); recent history of crop failure; farm income; distance to the nearest market; and adaptive capacity. Regarding the latter, questions related to the use of improved seed varieties and fertilizer, adjustments in cropping patterns, crop marketing, soil and water conservation, and access to extension services. Farmers were also asked a set of questions on perceptions of recent trends in the timing of rainfall, its predictability and amount, trends in temperature change (comparing the past three years to ten years prior), and measures they had taken to adapt to those perceived changes. Finally, farmers were asked about constraints limiting their ability to adapt to any perceived changes. The coded survey data were subsequently entered using Microsoft Excel 2010 and SPSS spreadsheet-based statistical packages.

The survey data were analyzed in a regression framework using Stata software. The main outcome for this analysis was farmer adaptation behavior [31-33,50]. In order to measure adaptation behavior, a simple index was generated by counting the number of farming adaptation behaviors named in the survey. This index ranges from 0 to 10 in the sample, with a mean of 4.4 , and is approximately normally distributed. The index variable was regressed using Ordinary Least Squares regression on explanatory variables of interest available from the full sample of 147 surveys. The key explanatory variables included climate awareness (information received from the Development "extension" Agent), literacy, number of neighbors, and if the farmer had experienced a crop failure in the past five years. Further, the economic status of the farmer was controlled for via inclusion of variables indicating farmer productivity (farm revenue per hectare), the number of cattle owned (a traditional form of wealth), and indicators for access to electricity and irrigation. Each of these variables was expected to have a positive relationship with the adaptation index, as they should enable a farmer to more readily engage in adaptation. Still, the relationships between them should not be interpreted as causal (given concerns about reverse causality), and our analysis is therefore primarily descriptive. Moreover, high levels of significance are not expected given the small sample size, the sensitivity of the available measurements, and the complexity of adaptation decision making. The regression model does include fixed effects by district, which best accounts for unobserved geographic characteristics that might help determine adaptation behaviors.

\subsection{Focus Groups with Key Informants}

Finally, focus group discussions (FGDs) were conducted during the field work mainly with community leaders and other farmers in 6 representative rural villages in the ZiwayShala basin. These FGDs allowed for more in depth probing on questions related to knowledge of climate change, and to assess more qualitatively what it meant for both them and their broader communities.

\section{Results and Discussions}

This section describes the main results of the study, beginning with the water quality assessments, analysis of its irrigation suitability, and then presenting the survey results.

\subsection{Water QUality and Suitability for Agriculture}

Various hydrochemical constituents present in irrigation water can negatively affect crop productivity and soil fertility. This is especially true for sources that are subject to evaporative enrichment, such as the surface waters of the MER. Given that farmers are likely to face dwindling supplies of water under climate change [25], they may seek to increase the use of more reliable sources such as lake water or groundwater, in order to substitute for or supplement increasingly unreliable rainfall and seasonal supplies. The most important constituents of concern for agriculture include several major ions $\left(\mathrm{Na}^{+}\right.$, $\mathrm{Cl}^{-}, \mathrm{HCO}_{3}{ }^{-}, \mathrm{Ca}^{2+}$ and $\left.\mathrm{Mg}^{2+}\right)$, and trace elements such as boron. Critical parameters that 
constrain soil permeability and crop yields are salinity (as electrical conductivity; EC), the sodium adsorption ratio (SAR), and residual sodium carbonate (RSC) [51-53]. The sample analysis indicated that most water sources have EC below $3000 \mu \mathrm{S} / \mathrm{cm}$ and SAR below 80 . Rivers and cold springs have EC below $500 \mu \mathrm{S} / \mathrm{cm}$ and SAR below 3 . The rift floor lakes range from fresh (e.g., Lake Ziway) to highly alkaline (e.g., Lake Chitu) (Figure 1). The EC levels of the highly alkaline lakes of Shala, Abijata, and Chitu were especially high, at $22,500,40,800$ and $45,800 \mu \mathrm{S} / \mathrm{cm}$, respectively.

\subsection{Effect of EC and SAR on Water Infiltration}

Excessive $\mathrm{Na}^{+}$and salinity concentrations in irrigation water create hazards for both soil and crops. High $\mathrm{Na}^{+}$content in irrigation water can enhance cation-exchange replacement of $\mathrm{Na}^{+}$in water for $\mathrm{Ca}^{2+}$ and $\mathrm{Mg}^{2+}$ ions in soil, thereby reducing soil permeability and water infiltration [43]. The suitability of the various sampled waters for infiltration was evaluated using the Ayers and Westcot [45] classification that shows the relationships between salinity and sodicity (Figure S1). Most samples fall in the ranges corresponding to severe infiltration reduction (Table 1). Even at low EC, the high SAR can cause water infiltration problems. While infiltration may sometimes remain acceptable when both SAR and EC values are high, salinity beyond the safe threshold for a crop may still inhibit yields by restricting the amount of soil water that is available. Specifically, crop yields tend to decline linearly beyond this threshold, especially in arid and semi-arid regions [54,55]. Vegetable crops are often particularly sensitive [54].

Table 1. Water source types and their suitability for irrigation based on the Ayers and Westcot [45]. classification.

\begin{tabular}{ccccc}
\hline Irrigation Water Quality & Groundwater Wells & Rivers & Lakes & Cold Springs \\
\hline Severe & 76 & 6 & 5 & 6 \\
Slight to moderate & 54 & 2 & 1 & 2 \\
No problem & 5 & 0 & 0 & 0 \\
\hline
\end{tabular}

Irrigation water quality was also evaluated using the USDA classification diagram (Richards, 1954) (Figure 3). The diagram classifies the suitability of water for agricultural purposes into four categories based on SAR and EC: SAR (S1, S2, S3 and S4), and salinity (C1, C2, C3 and C4) where 1, 2, 3, 4 represents low, medium, high and very high, respectively (Table 2). Eighteen of the groundwater samples and most of the cold spring and river samples from the study were found to lie in category C1-S1, with low salinity and low sodium, which indicates suitability for irrigation water in almost all soil types. Sixty groundwater samples including Lake Ziway fall in the category C2-S1 and C3-S1 (medium to high salinity and low sodium). Waters in these categories can be used for irrigation in almost all soil types with little danger of exchangeable sodium. Lake Ziway is indeed the only freshwater lake in the Rift that is intensively used for irrigation at this time. An additional four groundwater samples that fall into the medium salinity hazard class (C2) but have sodium levels ranging from S2 to S4 can still be used if accompanied by a moderate amount of leaching. 


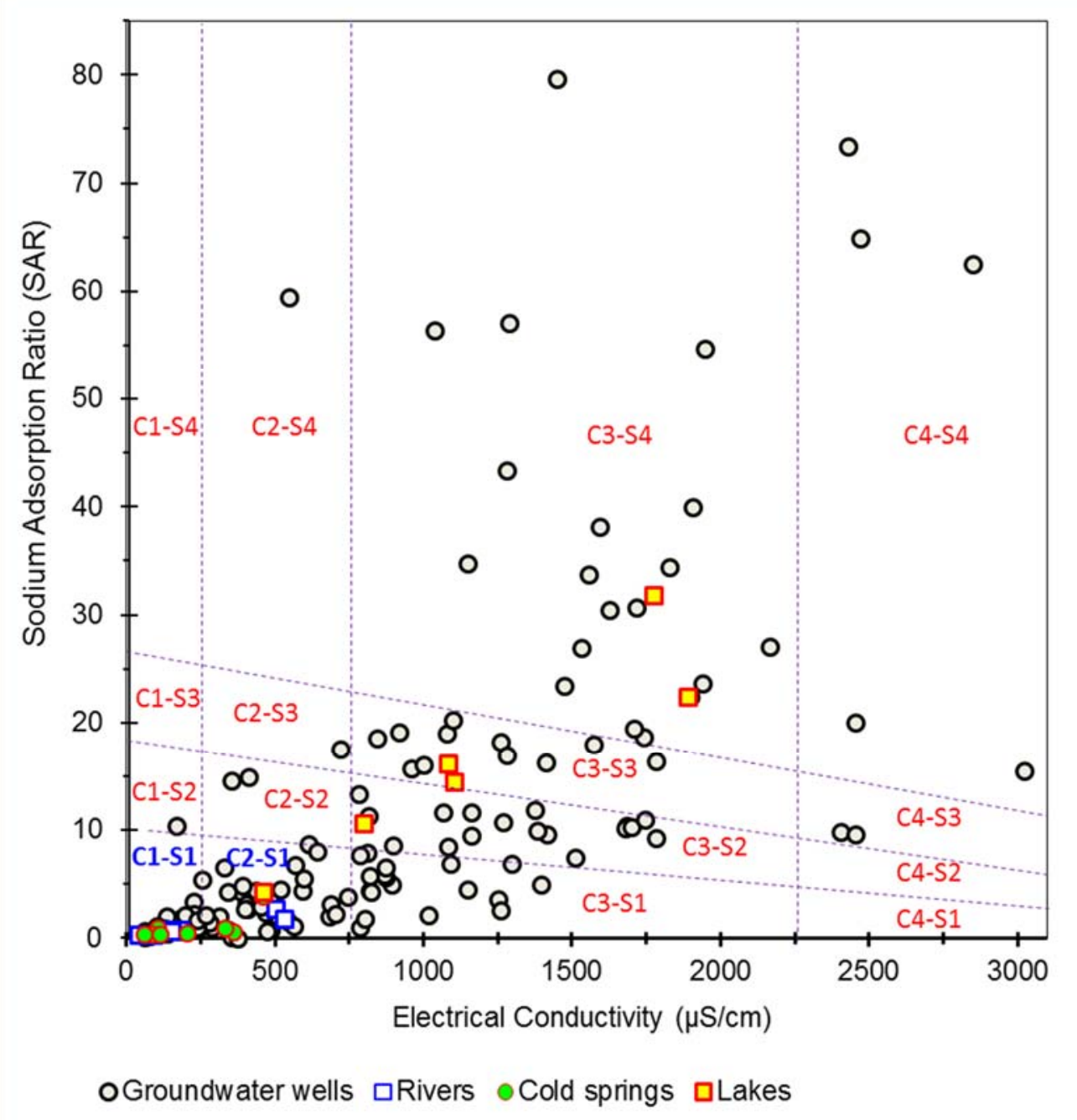

Figure 3. Suitability of water sources for irrigation, based on USDA classification (after Richards [46]).

Table 2. Water types and irrigation water classifications as shown in Figure 3.

\begin{tabular}{ccccc}
\hline & $\begin{array}{c}\text { Groundwater } \\
\text { Wells }\end{array}$ & Rivers & Lakes & $\begin{array}{c}\text { Cold } \\
\text { Springs }\end{array}$ \\
\hline C1S1 & 18 & 6 & - & 6 \\
C2S1 & 42 & 2 & 1 & 2 \\
C3S1 & 18 & - & - & - \\
C2S4 & 1 & - & - & - \\
C3S4 & 19 & - & 2 & - \\
C4S4 & 5 & - & - & - \\
C2S3 & 1 & - & - & - \\
C3S3 & 11 & - & 2 & - \\
C4S3 & 2 & - & - & - \\
C2S2 & 2 & - & - & - \\
C3S2 & 16 & - & 1 & - \\
C4S2 & - & - & 1 & \\
\hline
\end{tabular}

Most (71 groundwater samples and all lakes except Lake Ziway) samples, however, were categorized to be of high to very high salinity (C3 and C4), and medium to very high sodium (S2, S3 and S4). These samples cannot be used in soils with restricted drainage. Even with adequate drainage, special management for salinity control is typically required 
and salt-tolerant crops should be selected. Analyzing the spatial distribution of suitability for irrigation, it becomes apparent that most groundwater wells and rivers emerging from or nearer the highlands (including Lake Ziway) are suitable for irrigation with little danger to the soil and crops. The other lake and groundwater samples, however, would require treatment before application if they are to be used for irrigation over the long term.

An additional limiting factor for irrigation water is the presence of $\mathrm{HCO}_{3}{ }^{-}$anions, which can trigger carbonate precipitation and cause scaling in irrigation pipes and pumps. Saturation of carbonate minerals may reduce the $\mathrm{Ca}^{2+}$ and $\mathrm{Mg}^{+2}$ content of the soil water, and consequently increase SAR values. As described above, the RSC is an alternative measure of the $\mathrm{Na}^{+}$content in water that also accounts for $\mathrm{Ca}^{2+}$ and $\mathrm{Mg}^{+2}$. If $\mathrm{RSC}<1.25$, the water is considered safe, while $>2.5$ indicates that the water is not appropriate for irrigation. In the groundwater samples, RSC varied from -1.3 to 33.4; while 20 of the samples were found safe, $60 \%$ were deemed unsuitable for irrigation, with the remainder falling in between.

Different plants have varying tolerance to salinity, but adverse effects on crop yields are typically apparent at EC exceeding $1000 \mu \mathrm{S} / \mathrm{cm}$ [42]. Similarly, concentrations of boron above $0.5 \mathrm{mg} / \mathrm{L}$ significantly reduce crop yields, particularly for boron-sensitive crops such as strawberries, beans, onion, and garlic [42]. Figure 4 shows that the salinity and boron in a large proportion of the groundwater wells exceeds these threshold values.

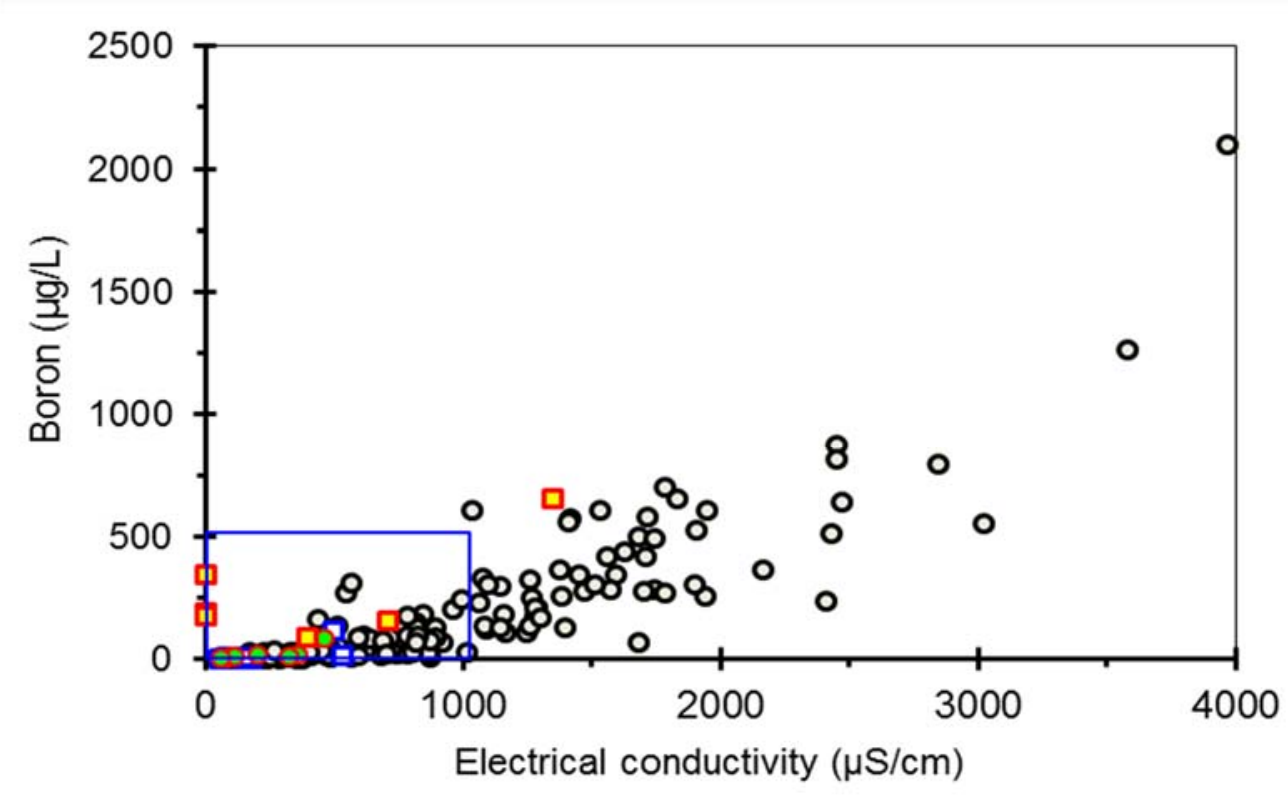

- Groundwaters aRivers $\bullet$ Cold springs aLakes

Figure 4. Variation of boron and electric conductivity (EC) in MER groundwater. The squared region indicates where values are acceptable for irrigation water, and values outside these areas suggest potential problems with sustained utilization.

All in all, these results indicate that sustained application of MER groundwater would likely not be possible due to water quality concerns. This limits the ability of irrigators to supplement irregular or insufficient surface water supplies with more dependable groundwater sources. Of course, for soils that have never been or are infrequently used, crop productivity is less likely to be harmed by high salinity water during the initial periods of use. Other factors such as climate, soil type, crop and plant species and management practices also need to be accounted for when identifying acceptable levels of irrigation water salinity and sodicity [54]. 


\section{Results of the Farm Surveys}

The 147 interviewed farmers are predominantly male $(94.6 \%, \mathrm{n}=139)$ and heads of their households (98.4\%). Males tend to be the primary agricultural decision-makers in Ethiopia [56]. More than $87 \%$ of the households are from the Oromo ethnic group. About $75 \%$ of the heads of household could read and write at the time of the survey, while $28 \%$ had had no formal education. The farming system of the study areas was dominated by mixed cropping and livestock husbandry (for $90 \%$ of the farmers), while a minority of farmers exclusively grew crops. Farm households depend on crops for both food and cash income. Below, we describe the main survey outcomes of the study, namely crop choice, use of irrigation, perceptions of climate stresses and change, factors determining good and bad crop yield, climate change impacts on agriculture, and adaptation practices and constraints.

\subsection{Crop Choice}

Across the different agro-climatic zones, at the time of the survey, farmers grew crops suitable to existing rainfall and temperature conditions. In the Rift floor areas $(<1750 \mathrm{~m})$, maize and teff were the predominant crops, but this area is also suitable for other cereals including wheat, haricot bean and sorghum. Farmers located at higher altitudes (1750-2100 m), meanwhile, grew mostly maize, wheat and teff, and highland $(>2100 \mathrm{~m}$ ) farmers predominantly produced wheat and barley. Other highland crops include fava bean, field pea and maize. These varying cropping patterns indicate that farmers are well-attuned to the historic climatic advantages in their specific locations. Still, farmers reported changes in the climate that are endangering their practices, especially in the lowlands. In the rift, farmers also use improved seed for crops such as of maize, wheat, barley and haricot bean as a primarily response to rainfall variability although access to these seeds is limited.

\subsection{Farmers' Irrigation Use}

Most farmers in the survey do not use irrigation, but rather rely on rainwater to cultivate cereal crops. Many farmers do view irrigation as an important opportunity to improve their agricultural system but lack the capacity or knowledge to access and utilized surface and groundwater sources. In the irrigated areas surveyed in the Rift Valley (at Arata and around Lake Ziway), farmers produce horticultural crops that include tomato, onion, pepper and cabbage. The farmers that use irrigation typically achieve better productivity and profits, although they also report occasionally losing their crops due to excessive rain, or lack of profit due to price reductions during productive periods. As demonstrated in the previous section on water quality and as shown in Figures 1 and 2, high quality water sources do exist in the region that could be or were already being used for irrigation. For instance, the existing and on-going development of the floriculture sector in the MER (such as Meki and Ziway towns in the MER) is mainly based on surface water (Lake Ziway and its rivers) resources. Most groundwater sources in the region are too poor in quality for agricultural use, however (e.g., Figure 1; red block area), and increased groundwater extraction may also threaten the sustainability of the aquifer, which is essential for many of the region's rural drinking water supplies. With regard to drinking water, these sources have also previously been shown to be contaminated with elevated levels of fluoride and arsenic $[38,39,57]$. Continued monitoring of the quantity and quality of the groundwater resources is essential to mitigate the associated negative impacts.

\subsection{Perceptions of Climate Stresses and Climate Change}

Most farmers reported in the survey that lack of rain is one of the main constraints to agricultural productivity. Many also indicated that they thought rainfall was becoming more erratic. Figure 5 shows farmers' perceptions of changes in the pattern of rainfall and temperature. More than $70 \%$ of the farmers stated that rain comes and stops later than expected, compared to ten years ago. Moreover, a majority perceives that the climate is 
drier, hotter, less predictable and generally worse for farming than it used to be, especially in lowland areas. A few farmers (6\%) report no changes in temperature and rain. Despite perceptions of more erratic precipitation, some farmers report that their farm output is improving due to their use of improved seeds and fertilizers.

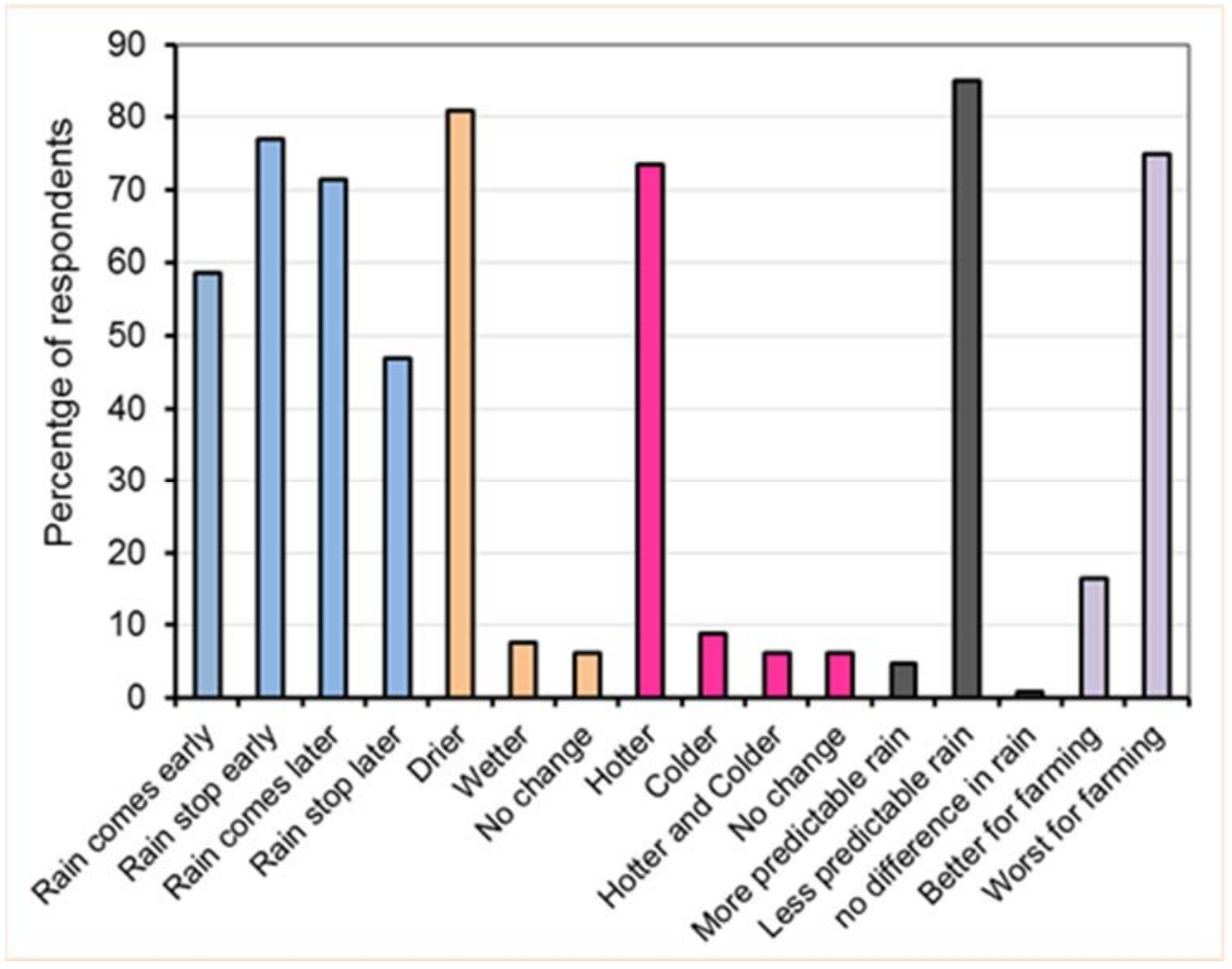

Figure 5. Farmer perceptions of climate change in the Ziway-Shala basin.

In focus groups, it was noted that farmers were generally aware that changes to the climate are becoming a serious problem. These changes are widely perceived as being related to rainfall variability (rain comes too early and stops too late, and is uneven in amount, whether too high or too low), and farmers in the Rift especially reported experiencing a significant reduction in overall rainfall, alongside extreme and unexpected, rare heavy rainfall episodes. In the highlands, complaints were primarily related to variability, rather than to the quantity of rainfall. Due to rainfall shortage in the Rift, farmers start planting drought-tolerant early maturing maize varieties, though there is limited supply of such seeds. In some cases when there has been no rainfall in April and May, farmers forgo planting entirely. Maize productivity is also decreasing from time to time; however, farmers are achieving enhanced returns by shifting to wheat, barley and teff cultivation.

\subsection{Factors Determining Good and Bad Crop Yield}

Farmers pointed out that uninterrupted and sufficient quantities of rain, availability of farming inputs (fertilizer and seeds), and personal efforts are the most important factors determining a good crop season and productivity (Figure 6). In contrast, lack of or excessive rain or unexpected rain, low crop price, lack of available and affordable inputs, and insufficient personal effort all contribute negatively to crop productivity and profit (Figure S2). Rainfall appears most important in these responses. The study revealed that insect pests and diseases are also major problems facing farmers in the region. 


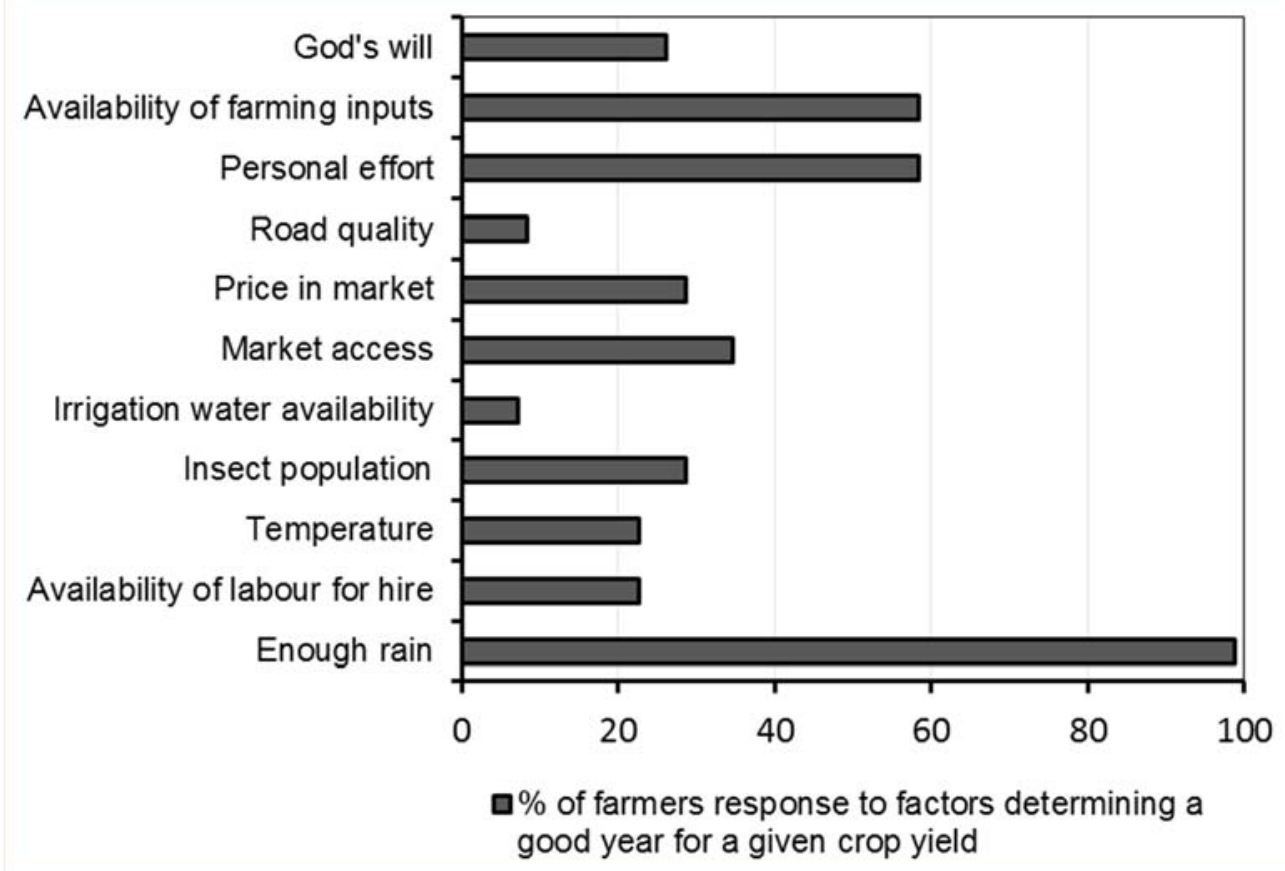

Figure 6. Relative importance of factors determining a good crop year.

\subsection{Climate Change Impacts on Agriculture, Adaptation Practices and Constraints}

In the 5 years prior to the survey, $66.7 \%$ of the farmers reported experiencing crop failure at least once. Crop failure occurred in the Rift floor $(<1750 \mathrm{~m})$ an average of 1.6 times in a 5-year period, in contrast to only 0.5 times in the highlands ( $>2100 \mathrm{~m}$ ). The majority $(80 \%)$ of farmers on the Rift floor and $22 \%$ in the highlands had experienced at least one crop failure in the 5 years preceding the survey. Table 3 shows the frequency of crop failure at different altitudes. Lack of rain (61\% of respondents) and unexpected rain $(27 \%)$ are the most important determinants of these frequent crop failures. Agriculture in the Rift faces about $76 \%$ more crop failures than in the highlands. Crop failures were stated as the cause of food shortages for some households, and a need for food assistance.

Table 3. Frequency of reported crop failures in the past 5-year at different elevations.

\begin{tabular}{ccccc}
\hline $\begin{array}{c}\text { Crop Failure } \\
\text { in the Past 5 Years }\end{array}$ & $\begin{array}{c}\mathbf{1 6 4 0 - 3 1 0 0 ~} \mathbf{m} \\
(\boldsymbol{n}=\mathbf{1 4 7})\end{array}$ & $\begin{array}{c}<\mathbf{1 7 5 0 ~} \mathbf{m} \\
(\boldsymbol{n}=\mathbf{7 6})\end{array}$ & $\begin{array}{c}\mathbf{1 7 5 0 - 2 1 0 0 ~} \mathbf{m} \\
(\boldsymbol{n}=\mathbf{3 5})\end{array}$ & $\begin{array}{c}>\mathbf{2 1 0 0} \mathbf{m}, \text { Elevation. } \\
(\boldsymbol{n}=\mathbf{3 6})\end{array}$ \\
\hline & 33.3 & \multicolumn{3}{c}{ Percentage of respondents } \\
1 & 24.5 & 19.7 & 17.1 & 77.8 \\
2 & 25.2 & 23.7 & 48.6 & 2.8 \\
3 & 16.3 & 34.2 & 20.0 & 11.1 \\
4 & 0.68 & 22.4 & 11.4 & 8.3 \\
Average crop failure & 1.14 & 0.0 & 2.9 & 0.0 \\
\hline
\end{tabular}

Practices that farmers are implementing to improve their farming, as reported in the survey, are summarized in Figure 7 . About $70 \%$ of sample respondents stated that they use high yield crop varieties or early maturing seeds. A large proportion of farmers use fertilizer - mostly DAP (Diammonium Phosphate) and urea — and roughly half of them practice crop rotation to improve soil conditions and yield, and to minimize the buildup of weeds, insect pests and plant diseases. The most common crop rotations are between cereal crops. Among irrigators, vegetables and cereals are also commonly rotated. Farmers use terracing and afforestation, conserve seeds and other natural resources, and use irrigation 
as key practices to improve productivity. A few wealthy farmers in the highlands use mechanized technology (e.g., renting tractors) to quickly collect crops during harvest.

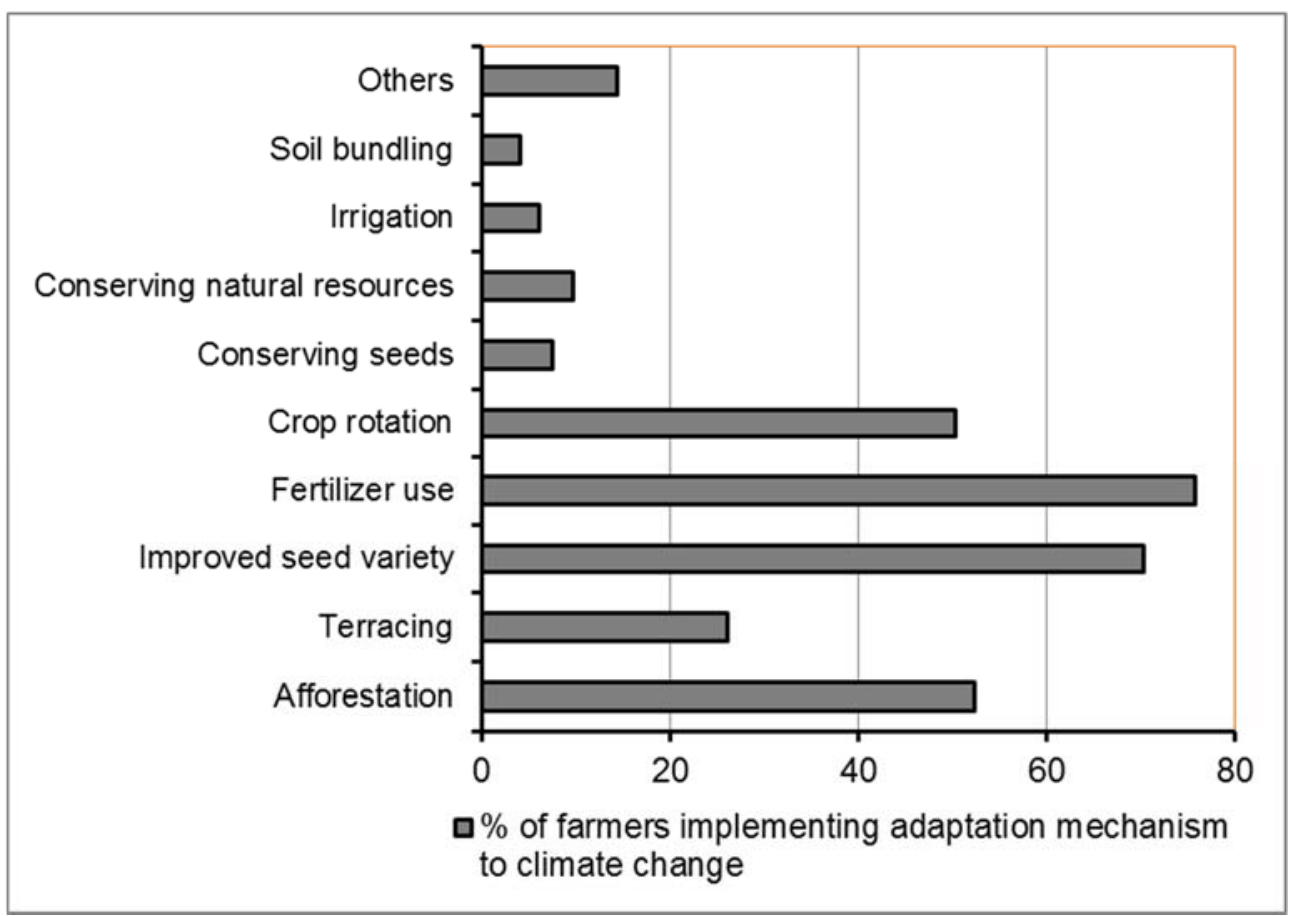

Figure 7. Different measures farmers use to improve productivity.

As a response to rainfall shortages, farmers in the Rift reported increasing planting of drought-resistant early maturing maize varieties (as well as wheat, haricot, and barley), though there is limited supply of such seeds. Farmers sometimes skip planting maize when the rains fail in April and May, and many were shifting away from maize in favor of wheat, barley and teff. In focus groups, many farmers argued that deforestation for firewood and charcoal production were major contributors to environmental or climate changes and expressed concern over the loss of pollinators from overuse of chemical pesticides in the area's floriculture farms. Farmers in several sites indicated they were involved in the protection and planting of new trees (i.e., area closure plans), as part of efforts organized by the regional government, while others mentioned projects to build ponds, enhance water conservation and flood protection, replace chemical fertilizer with manure/compost, and increase crop rotation and diversity to respond to climate stresses. Furthermore, farmers noted that over 350 million trees had been planted in one day (29 July 2019) across the country as part of Ethiopia's Green Legacy Initiative, setting a new record. This effort was conceived to help counter the effects of deforestation and climate change.

Lack of access to water, credit or savings, knowledge, information on weather and climate change were identified as major barriers to adaptation to climate and environmental change (Figure S3). Some farmers in the Rift Valley are also reluctant to take available loans when they get access to credit, due to the high uncertainty concerning rainfall, and the associated risk of crop failure and inability to pay back loans. Farmers unable to pay their loans are sometimes forced to sell to livestock or end up mired in bad debts. While market access or transportation was not identified as a major barrier to adaptation, many farmers noted that markets do not function in a way that allows them to maximize earnings. Specifically, more than $50 \%$ of farmers sell their crops within 3 months of harvest, which is also the period when prices are lowest. Farmers feel that they have limited bargaining power over prices, which are typically set by local traders. Farmers associations are nonetheless trying to organize to purchase crops from local farmers while the price is low, so as to sell them to the market when prices rise, and allow for increased revenues. 
The regression analysis (Table 4) reveals relevant patterns in the determinants of farmer adaptation to climate change. While receipt of information on climate change does not significantly predict adaptation, it does have a positive relationship as would be predicted based on the role of Development Agents in transmitting information. Other studies have similarly found that extension services are positively associated with adaptation, presumably reflecting access to information and other resources that empower farm households to adjust to climate risks [32,50]. Farmer literacy is positive and significant at the $p<0.10$ level, which is suggestive of a greater ability to receive and process information from external sources, or of correlation with higher socio-economic status and ability to adapt. Farmer productivity (farm revenue per hectare) also has a positive and statistically significant correlation with adaptation at the $p<0.10$ level, even when controlling for other measures of wealth and economic well-being (though this may also indicate that adaptation leads to greater productivity). While not significant, several other variables have a positive relationship with adaptation, such as experience with crop failure and the number of neighbors. Farmers must take into account a large variety of factors and both individual and community characteristics in order to determine how and when to adapt [58].

Table 4. Regression of adaptation behaviors on farmer characteristics.

\begin{tabular}{cc}
\hline Variables & Adaptation Index \\
\hline Climate Information from Development Agent & $0.25(0.517)$ \\
Literacy & $0.72 *(0.428)$ \\
Number of Proximate Neighbors & $0.05(0.114)$ \\
Experienced Crop Failure in Prior 5 years & $0.51(0.461)$ \\
Log Productivity (Revenue/Ha) & $0.33 *(0.171)$ \\
Cattle Owned & $0.01(0.031)$ \\
Access to Electricity & $0.03(0.572)$ \\
Access to Irrigation & $-0.0(0.564)$ \\
Constant & $0.51(1.786)$ \\
Observations & 147 \\
R-squared & 0.135 \\
District Fixed Effects & Yes \\
\hline
\end{tabular}

Standard errors in parentheses; ${ }^{*} p<0.1$.

\section{Conclusions, Policy Implications, and Future Work}

Climate change impact assessment studies have shown changes in the quantity and variability of rainfall, as well as rising temperatures in Ethiopia-by an average of $1{ }^{\circ} \mathrm{C}$ since 1960, which is projected to increase by $1.81^{\circ} \mathrm{C}$ in $2040-2059$ [59]. Climate change is threatening rainfed agriculture and rural livelihoods in many parts of the world, especially in highly vulnerable regions and in low-income countries in Africa, such as Ethiopia. The location of this study, the Rift Valley of Ethiopia, is highly vulnerable to climate stressors $[5,20,60]$. Our study relied on the analysis of primary data on water quality, obtained to evaluate the suitability of different sources for irrigation, as well as survey data pertaining to farmers' perceptions, their adaptation behaviors, and general barriers that challenge adaptation in the MER.

The most salient climate-related shocks in the region are a lack of rainfall and the high variability of rainfall, and crop failures are common. The study also identified several adaptation mechanisms undertaken by households in response to climate-related shocks: the use of new high yield crop varieties, early maturing seeds, increased fertilizer application, and changing crop rotations. They also use terracing, afforestation, seed saving, the conservation of natural resources and irrigation to increase productivity, reduce risk, and control environmental degradation. Irrigation is a common adaptation response to reduced water availability globally, but our assessments of the suitability of irrigation water point to several threats in the MER. First, judging by measures of EC and SAR, most water sources are categorized as having severe or slight to moderate negative implications for 
soil permeability and reduced water infiltration. In addition, high bicarbonate and boron concentrations pose water quality threats for cultivation.

It is observed that the role of Extension ("Development") Agents (DAs) is vital to enhancing farmers' knowledge of potential adaptation strategies. This service is currently available in the study basin and is critical for increasing farmers' adaptability in the face of continuing climatic variability. Meanwhile, the main barriers to adaptation include a lack of access to water, credit or savings, lack of appropriate seeds, knowledge and information on weather and climate. Improving access to credit, increased ability to arbitrage sales over seasons with high market prices for local agricultural products, enhancing access and distribution of sufficient seeds (in variety and amounts), early warning on weather during planting and harvesting seasons, and knowledge transfer on effective farming practices (e.g., the use of fertilizers that are suitable and proper amount for a given soil type) are some of the measures that should to be taken to improve farmers' productivity and adaptive capacity to climate change.

Based on the findings of this study, it would be unwise to further develop irrigated agriculture without establishing that water sources being exploited in specific sites are of sufficient quality. Nonetheless, the viability of rain-fed agriculture is clearly threatened by the changing climate, and crop failures are increasingly prevalent in communities, particularly those located in the Rift floor. This situation calls for careful planning of alternative livelihoods strategies for households, by decision-makers who understand these challenges and are willing to design new strategies for adaptation, food security, and enhanced rural well-being.

\subsection{Water and Farmers' Survey Data Collection Time and Its Implication in the Study Area}

While the data collection was carried out over a decade ago, it provides useful and rich reference information that can be used as a baseline for examining future changes pertaining to a very data limited region. We use these data to assess the dynamics inherent in farming practices, farmers' perceptions of and adaptation to changing climate and crop productivity, in a context where climatic changes were already being experienced in significant ways. Observing the livelihood of the communities in this region over time, we are confident that no major changes in practices have occurred currently and that agriculture remains unproductive, with the use of antiquated farming practices, very limited or no technology use, and low capacity and resources to invest in improved productivity. Given most groundwater sources in the Rift are not suitable for agriculture due to salinity, which is one of the reasons for the increased pressure on the use of the fresh water sources from Ziway lake and its tributaries. Subsistence agriculture continues to be the main source of income for most farmers in the region. While it may be necessary to monitor specific changes in farmers' behavior and practices over the recent period, we do not anticipate significant changes given that farmers have generally remained in similar conditions marked by a lack of capacity to respond to changing environmental conditions. This includes responses to climate variability and trends, which have increased vulnerability relative to conditions experienced ten years ago.

\subsection{Implication of the Study to Current and Future Local Policies}

Our findings on adaptation and barriers to adaptation suggest the need to intensify agricultural productivity by increasing irrigation and technology use in the farming practices in the region. This will improve farmers' food security and income. Considering the farmers' high reliance on unpredictable rainwater for agriculture, policy driven actions that support irrigation use, with particular attention not only to water availability but also to water quality, are critical. Enforcing the regulation of water quality is particularly important to avoid salinization of the soil, which may further exacerbate declining crop productivity in the face of ongoing climate warming. Since freshwater scarcity in the region is prevalent, water use is more determined by its availability or quantity than water quality in the region. 


\subsection{Future Work}

Our study highlighted water quality issues that could threaten irrigation-based adaptation in the MER, while demonstrating that the region's farmers perceive changes in climate (temperature and rainfall variability) but are limited in their ability to adapt to them. These results can be useful as baseline information for additional in-depth studies on the impacts of surface and ground water irrigation use on soil salinity and agricultural productivity. Further work should be carried out to identify suitable water management strategies that address water scarcity while paying heed to water quality challenges (e.g., high salinity, SAR, and bicarbonate). In addition, the study showed the dependence of farmers on specific seed varieties (early maturing, drought-tolerant, and high yielding crops) whose supply is limited, and whose uptake may have other unintended long-term consequences. High-yield seed varieties that are suitable for saline soil or viable in arid and semi-arid conditions continue to be needed, and soil stability and recovery must be carefully considered in future work.

Supplementary Materials: The following are available online at https://www.mdpi.com/article/10 $.3390 /$ cli9060092/s1.

Author Contributions: T.R.G.: Design of study concept, conducted the field work, data analysis and interpretation, wrote the manuscript, and funding acquisition. M.A.J.: Design of study concept, critical revision of the manuscript for important intellectual content, and funding acquisition. C.J.P. and P.G.M.: Data analysis and interpretation, critical revision of the manuscript for important intellectual content. D.L.B.: Field work assistance, revision of the manuscript for important intellectual content and funding acquisition. All authors have read and agreed to the published version of the manuscript.

Funding: We are grateful to the grant from START's Global Environmental Change Research in Africa under the theme climate change, agriculture, and food security with an emphasis on the sustainability of ecosystem services.

Institutional Review Board Statement: The study protocol was approved under Duke University's Institutional Review Board (protocol number A0741).

Informed Consent Statement: All respondents provided informed consent prior to participation in the study. The confidentiality and anonymity of survey respondents has been maintained.

Data Availability Statement: Survey and water quality data of this study can be provided upon request.

Acknowledgments: We would like to thank the farmers who participated in the study for their interest, cooperation and partnership. We would like to thank the Kulumsa Agricultural Research Center (KARC) employees who participated in the agricultural survey interview (Eshetu Lemma and Tarekegn Etana) and for facilitating and guiding us through the field work. We also give special thanks to Skip Kaufmann for his consistent support throughout the project; he helped ensure smooth execution of the project and achievement of its aims.

Conflicts of Interest: All authors confirm that they have no financial or non-financial interests.

\section{References}

1. IPCC. Climate Change 2014: Impacts, Adaptation, and Vulnerability; Part A: Global and Sectoral Aspects; Field, C.B., Barros, V.R., Dokken, D.J., Mach, K.J., Mastrandrea, M.D., Bilir, T.E., Chatterjee, M., Ebi, K.L., Estrada, Y.O., Genova, R.C., et al., Eds.; Cambridge University Press: Cambridge, UK; New York, NY, USA, 2014.

2. IPCC. Climate Change 2007: The Physical Science Basis; Solomon, S., Qin, D., Manning, M., Chen, Z., Marquis, M., Averyt, K.B., Tignor, M., Miller, H.L., Eds.; Cambridge University Press: New York, NY, USA, 2007.

3. IPCC. Climate Change 2001: Impacts, Adaptations and Vulnerability; Cambridge University Press: Cambridge, UK, 2001.

4. Challinor, A.; Wheeler, T.; Garforth, C.; Craufurd, P.; Kassam, A. Assessing the vulnerability of food crop systems in Africa to climate change. Clim. Chang. 2007, 83, 381-399. [CrossRef]

5. Thornton, P.K.; Jones, P.G.; Owiyo, T.; Kruska, R.L.; Herrero, M.T.; Kristjanson, P.M.; Notenbaert, A.M.O.; Bekele, N.; Omolo, A. Mapping Climate Vulnerability and Poverty in Africa; Report to the Department for International Development; ILRI: Nairobi, Kenya, 2006; p. 200. 
6. Cui, Z.; Zhang, H.; Chen, X.; Zhang, C.; Ma, W.; Huang, C.; Zhang, W.; Mi, G.; Miao, Y.; Li, X.; et al. Pursuing sustainable productivity with millions of smallholder farmers. Nat. Cell Biol. 2018, 555, 363-366. [CrossRef]

7. Lesk, C.; Rowhani, P.; Ramankutty, N. Influence of extreme weather disasters on global crop production. Nat. Cell Biol. 2016, 529, 84-87. [CrossRef]

8. He, Q.; Zhou, G. Climate-associated distribution of summer maize in China from 1961 to 2010. Agric. Ecosyst. Environ. 2016, 232, 326-335. [CrossRef]

9. Asseng, S.; Ewert, F.; Martre, P.; Rotter, R.P.; Lobell, D.B.; Cammarano, D.; Kimball, B.A.; Ottman, M.J.; Wall, G.W.; White, J.W.; et al. Rising temperatures reduce global wheat production. Nat. Clim. Chang. 2015, 5, 143-147. [CrossRef]

10. Conway, D.; Schipper, E.L.F. Adaptation to climate change in Africa: Challenges and opportunities identified from Ethiopia. Glob. Environ. Chang. 2011, 21, 227-237. [CrossRef]

11. Rosell, S. Regional perspective on rainfall change and variability in the central highlands of Ethiopia, 1978-2007. Appl. Geogr. 2011, 31, 329-338. [CrossRef]

12. Tilahun, H.; Teklu, E.; Michael, M.; Fitsum, H.; Awulachew, S.B. Comparative Performance of Irrigated and Rainfed Agriculture in Ethiopia. World Appl. Sci. J. 2011, 14, 235-244.

13. Von Grebmer, K.; Bernstein, J.; de Waal, A.; Prasai, N.; Yin, S.; Yohannes, Y. 2015 Global Hunger Index: Armed Conflict and the Challenge of Hunger; International Food Policy Research Institute: Washington, DC, USA, 2015.

14. IFAD. Highlights Annual Report. 2012. Available online: https://www.ifad.org/en/web/knowledge/publication/asset/391848 43 (accessed on 5 March 2021).

15. Legesse, D.T.; Abiye, A.; Vallet-Coulomb, C.; Abate, H. Streamflow sensitivity to climate and land cover changes: Meki River, Ethiopia. Hydrol. Earth Syst. Sci. 2010, 14, 1-11. [CrossRef]

16. Legesse, D.; Vallet-Coulomb, C.; Gasse, F. Analysis of the hydrological response of a tropical terminal lake, Lake Abiyata (Main Ethiopian Rift Valley) to changes in climate and human activities. Hydrol. Process. 2004, 18, 487-504. [CrossRef]

17. Alemayehu, T.; Furi, W.; Legesse, D. Impact of water overexploitation on highland lakes of eastern Ethiopia. Environ. Earth Sci. 2007, 52, 147-154. [CrossRef]

18. World Bank. 2019. Available online: https://data.worldbank.org/country/ethiopia (accessed on 12 February 2021).

19. Byerlee, D.; Spielman, D.J.; Alemu, D.; Gautam, M. Policies to Promote Cereal Intensification in Ethiopia: A Review of Evidence and Experience; Discussion Paper 00707; International Food Policy Research Institute, Development Strategy and Governance Division: Washington, DC, USA, 2007.

20. World Bank. Managing Water Resources to Maximise Sustainable Growth: A Country Water Resources Assistance Strategy for Ethiopia; World Bank: Washington, DC, USA, 2006.

21. World Bank Country Profile. 2018. Available online: https://databank.worldbank.org/views/reports/reportwidget.aspx? Report_Name=CountryProfile\&Id=b450fd57\&tbar=y\&dd=y\&inf=n\&zm=n\&country=ETH (accessed on 20 February 2021).

22. Byerlee, D.; Stevenson, J.; Villoria, N. Does intensification slow crop land expansion or encourage deforestation? Glob. Food Secur. 2014, 3, 92-98. [CrossRef]

23. Taffesse, A.S.; Dorosh, P.; Gemessa, S.A. 3 Crop Production in Ethiopia: Regional Patterns and Trends. Food Agric. Ethiop. 2014, 53. [CrossRef]

24. Muluneh, A.; Bewket, W.; Keesstra, S.; Stroosnijder, L. Searching for evidence of changes in extreme rainfall indices in the Central Rift Valley of Ethiopia. Theor. Appl. Clim. 2017, 128, 795-809. [CrossRef]

25. Li, L.; Li, W.; Ballard, T.; Sun, G.; Jeuland, M. CMIP5 model simulations of Ethiopian Kiremt-season precipitation: Current climate and future changes. Clim. Dyn. 2016, 46, 2883-2895. [CrossRef]

26. Paul, C.J.; Jeuland, M.A.; Godebo, T.R.; Weinthal, E. Communities coping with risks: Household water choice and environmental health in the Ethiopian Rift Valley. Environ. Sci. Policy 2018, 86, 85-94. [CrossRef]

27. Kassie, B.T.; Rötter, R.P.; Hengsdijk, H.; Asseng, S.; Van Ittersum, M.K.; Kahiluoto, H.; Van Keulen, H. Climate variability and change in the Central Rift Valley of Ethiopia: Challenges for rainfed crop production. J. Agric. Sci. 2013, 152, 58-74. [CrossRef]

28. Calow, R.C.; Macdonald, A.M.; Nicol, A.L.; Robins, N.S. Ground Water Security and Drought in Africa: Linking Availability, Access, and Demand. Ground Water 2010, 48, 246-256. [CrossRef]

29. Adimassu, Z.; Kessler, A. Factors affecting farmers' coping and adaptation strategies to perceived trends of declining rainfall and crop productivity in the central Rift valley of Ethiopia. Environ. Syst. Res. 2016, 5, 255. [CrossRef]

30. Adimassu, Z.; Kessler, A.; Stroosnijder, L. Farmers' strategies to perceived trends of rainfall and crop productivity in the Central Rift Valley of Ethiopia. Environ. Dev. 2014, 11, 123-140. [CrossRef]

31. Sadiq, M.A.; Al-Hassan, R.M.; Kuwornu, J.K.M. Vulnerability of Smallholder Maize Farming Households to Climate Variability in the Eastern Region of Ghana. In Climate Change and Sub-Saharan Africa: The Vulnerability and Adaptation of Food Supply Chain Actors; Kuwornu, J.K.M., Ed.; Vernon Press: Wilmington, DE, USA, 2019; pp. 173-189.

32. Deressa, T.T.; Hassan, R.M.; Ringler, C.; Alemu, T.; Yesuf, M. Determinants of farmers' choice of adaptation methods to climate change in the Nile Basin of Ethiopia. Glob. Environ. Chang. 2009, 19, 248-255. [CrossRef]

33. Dinar, A.; Hassan, R.; Mendelsohn, R.; Benhin, J. Climate Change and Agriculture in Africa. Impact Assessment and Adaptation Strategies; Earthscan: London, UK; Centre for Environmental Economics and Policy in Africa (CEEPA): London, UK, 2008 ; p. 189. ISBN 9781844075478. 
34. Mendelsohn, K. A Ricardian analysis of the impact of climate change on African cropland. Afr. J. Agric. Resour. Econ. 2008, 2, $1-23$.

35. Hussain, S.S.; Mudasser, M. Prospects for wheat production under changing climate in mountain areas of Pakistan-An econometric analysis. Agric. Syst. 2007, 94, 494-501. [CrossRef]

36. Daugherty Water for Food Global Institute. Pathways to Increasing Farmer-Led Investments in Sustainable Agricultural Water Management in Sub-Saharan Africa; DWFI Working Paper; DWFI: Lincoln, NE, USA, 2018.

37. Lankford, B.A.; Makin, I.; Matthews, N.; Noble, A.; McCornick, P.G.; Shah, T. A compact to revitalise large-scale irrigation systems using a leadership-partnership-ownership 'Theory of change'. Water Altern. 2016, 9, 1-32.

38. Rango, T.; Vengosh, A.; Dwyer, G.; Bianchini, G. Mobilization of arsenic and other naturally occurring contaminants in groundwater of the Main Ethiopian Rift aquifers. Water Res. 2013, 47, 5801-5818. [CrossRef] [PubMed]

39. Rango, T.; Kravchenko, J.; Atlaw, B.; McCornick, P.G.; Jeuland, M.; Merola, B.; Vengosh, A. Groundwater quality and its health impact: An assessment of dental fluorosis in rural inhabitants of the Main Ethiopian Rift. Environ. Int. 2012, 43, 37-47. [CrossRef] [PubMed]

40. Al-Bassam, A.M.; Al-Rumikhani, Y.A. Integrated hydrochemical method of water quality assessment for irrigation in arid areas: Application to the Jilh aquifer, Saudi Arabia. J. Afr. Earth Sci. 2003, 36, 345-356. [CrossRef]

41. Ayers, R.S.; Westcot, D.W. Water Quality for Agriculture; Food and Agriculture Organization of the United Nations: Rome, Italy, 1985.

42. Richards, L.A. Diagnosis Improvement Saline Alkali Soils; US Department of Agriculture Handbook, No. 60; Soil and Water Conservative Research Branch, Agricultural Research Service, US Department of Agriculture: Morris, MN, USA, 1954.

43. Naseh, M.R.V.; Noori, R.; Berndtsson, R.; Adamowski, J.; Sadatipour, E. Groundwater Pollution Sources Apportionment in the Ghaen Plain, Iran. Int. J. Environ. Res. Public Health 2018, 15, 172. [CrossRef]

44. Nishanthiny, S.C.; Thushyanthy, M.; Barathithasan, T.; Saravanan, S. Irrigation water quality based on hydro chemical analysis, Jaffna, Sri Lanka. Am. Eurasian J. Agric. Environ. Sci. 2010, 7, 100-102.

45. Grattan, S. Irrigation Water Salinity and Crop Production; University of California Agriculture and Natural Resources: Davis, CA, USA, 2002.

46. Shaki, A.; Adeloye, A. Evaluation of quantity and quality of irrigation water at Gadowa irrigation project in Murzuq basin, southwest Libya. Agric. Water Manag. 2006, 84, 193-201. [CrossRef]

47. Vallet-Coulomb, C.; Legesse, D.; Gasse, F.; Travi, Y.; Chernet, T. Lake evaporation estimates in tropical Africa (Lake Ziway, Ethiopia). J. Hydrol. 2001, 245, 1-18. [CrossRef]

48. NRMRD-MOA. Agro-Ecological Zones of Ethiopia; Natural Resources Management and Regulation Department of MOA: Addis Ababa, Ethiopia, 1998.

49. Le Turdu, C.; Tiercelin, J.J.; Gibert, E.; Travi, Y.; Lezzar, K.E.; Richert, J.P.; Massault, M.; Gasse, F.; Bonnefille, R.; Decobert, M.; et al. The Ziway Shala lake basin system, Main Ethiopian Rift: Influence of volcanism, tectonics, and climatic forcing on basin formation and sedimentation. Paleogeogr. Palaeoclimatol. Palaeoecol. 1999, 150, 135-177. [CrossRef]

50. Abid, M.; Scheffran, J.; Schneider, U.; Ashfaq, M. Farmers' perceptions of and adaptation strategies to climate change and their determinants: The case of Punjab province, Pakistan. Earth Syst. Dyn. 2015, 6, 225-243. [CrossRef]

51. Sadashivaiah, C.; Ramakrishnaiah, C.R.; Ranganna, G. Hydrochemical analysis and evaluation of groundwater quality in Tumkur Taluk, Karnataka State, India. Int. J. Environ. Res. Public Health 2008, 5, 158-164. [CrossRef]

52. Fipps, G. Irrigation Water Quality Standards and Salinity Management Strategies; Texas Agricultural Extension Service, Texas A\&M University System: College Station, TX, USA, 2003; pp. 1-19.

53. Zhang, H. Classification of Irrigation Water Quality. Oklahoma Cooperative Extension Service Id: PSS-2401. 2017. Available online: https:/ / extension.okstate.edu/fact-sheets/classification-of-irrigation-water-quality.html (accessed on 3 June 2021).

54. Zörb, C.; Geilfus, C.; Dietz, K. Salinity and crop yield. Plant Biol. 2019, 21, 31-38. [CrossRef] [PubMed]

55. Maas, E.V.; Hoffman, G.J. Crop Salt Tolerance: Evaluation of Existing Data. In Proceedings of the International Salinity Conference, Lubbock, TX, USA, 16-20 August 1976; pp. 187-198.

56. Gebre, G.G.; Hiroshi, I.; Dil Bahadur, R.; Yuichiro, A.; Hisako, N. Gender Gaps in Market Participation Among Individual and Joint Decision-Making Farm Households: Evidence from Southern Ethiopia. Eur. J. Dev. Res. 2021, 33, 649-683. [CrossRef]

57. Rango, T.; Paul, C.J.; Jeuland, M.; Tekle-Haimanot, R. Biomonitoring of metals and trace elements in urine of central Ethiopian populations. Int. J. Hyg. Environ. Health 2019, 222, 410-418.

58. Paul, C.J.; Weinthal, E.S.; Bellemare, M.F.; Jeuland, M.A. Social capital, trust, and adaptation to climate change: Evidence from rural Ethiopia. Glob. Environ. Chang. 2016, 36, 124-138. [CrossRef]

59. WBG Climate Change Knowledge Portal (CCKP). Ethiopia Projected Future Climate. 2020. Available online: https:// climateknowledgeportal.worldbank.org/country/ethiopia/climate-data-projections (accessed on 3 April 2021).

60. Boko, M.; Niang, I.; Nyong, A.; Vogel, C.; Githeko, A.; Medany, M.; Osman-Elasha, B.; Tabo, R.; Yanda, P. Africa. In Climate Change 2007: Impacts, Adaptation and Vulnerability; Parry, M.L., Canziani, O.F., Palutikof, J.P., van der Linden, P.J., Hanson, C.E., Eds.; Cambridge University Press: Cambridge, UK; New York, NY, USA, 2007; pp. 433-467. 